\title{
Bacterial Contamination of Used Manual Toothbrushes Obtained from Some Students of Nnamdi Azikiwe University Awka, Nigeria
}

\author{
Onuorah Samuel $^{1, *}$, Obika Ifeanyi ${ }^{2}$ \\ ${ }^{1}$ Department of Applied Microbiology and Brewing, Nnamdi Azikiwe University, Nigeria \\ ${ }^{2}$ Department of Zoology, Nnamdi Azikiwe University, Nigeria
}

Copyright (C) 2015 by authors, all rights reserved. Authors agree that this article remains permanently open access under the terms of the Creative Commons Attribution License 4.0 International License

\begin{abstract}
Used Toothbrushes serve as reservoirs for microorganisms and may play a major role in disease transmission in humans. Forty used manual toothbrushes obtained from some students of Nnamdi Azikiwe University Awka, Nigeria were analyzed bacteriologically using standard microbiological techniques. The toothbrushes were used twice per day for one month by the students. The result showed that all the toothbrushes were contaminated with bacteria while the unused ones which served as controls were not contaminated. The bacterial isolates from the toothbrushes were Streptococcus mutans, Pseudomonas aeruginosa, Staphylococcus aureus, Staphylococcus epidermidis, Escherichia coli, and Enterobacter aurogenes. Staphylococcus aureus was predominantly isolated $(30 \%)$ from the toothbrushes, followed by Pseudomonas aeruginosa (22\%), Staphylococcus epidermidis (18\%), Streptococcus mutans (16\%), Escherichia coli (8\%) and finally Enterobacter aerogenes (6\%). Staphylococcus aureus, Pseudomonas aeruginosa, Staphylococcus epidermidis, Streptococcus mutans, Escharichia coli and Enterobacter aerogenes were detected in 60\%, 45\%, 50\%, $25 \%, 20 \%$ and $10 \%$ of the samples respectively. In view of the fact that these organisms are pathogenic and could be a potential health hazard, adequate rinsing and air-drying of the toothbrushes before storage will minimize the incidence of these bacteria and the health risk associated with them.
\end{abstract}

Keywords Bacteria Contamination, Used Manual Toothbrushes, Students, Nnamdi Azikiwe University, Nigeria

\section{Introduction}

The oral cavity contains a teaming population of different types of microorganisms [1], some of which are transferred to a toothbrush during use. Toothbrushing plays an important everyday role for personal oral hygiene and effective plaque removal. It is the most commonly recommended and performed oral hygiene behaviour and is done ubiquitously in both developed and developing world.

The toothbrush is used on a daily basis to clean the oral cavity. A new toothbrush is usually not a favourable habitat for bacteria and fungi but in some cases, toothbrushes are already slightly infected before use [2,3]. Toothbrushes are shown to be contaminated at the oral cavity environment and from hands, aerosols and the storage environments [4,5].

The typical storage conditions of toothbrushes may act as a reservoir for the re-introduction of potential pathogens to the oral cavity and for the introduction of other potential pathogens from the bathroom environment. These microorganisms have the potential to colonize the oral cavity due to the micro-trauma that toothbrushing can cause [6]. Bacteria which attach to, accumulate and survive on toothbrushes may be transmitted to the individual, causing disease $[7,8]$.

Several articles have reported the bacterial and fungal contamination of brushes, with higher or lower contamination being associated with numerous interferences placed between the brush and the handle [1]. Toothbrush has been characterized as a means of microbial transport, retention and growth and highly contaminated brushes may cause a possible constant re-infection which is a risk factor for periodontal disease [9].

Toothbrushes play an essential role in oral hygiene and are generally found in community and hospital settings [4]. They have been reported to be heavily contaminated with microorganisms when in regular use [10.11] and may play significant role in disease transmission and increase the risk of infection since they serve as a reservoir for microorganisms in healthy, oral-diseased and medically-ill adults $[2,12]$.

Contaminated toothbrushes have been suggested to play a role in both systemic and localized diseases. The possibility of toothbrushes being associated with the transmission of 
heart diseases, arthritis, bacteremia and stroke have also been reported $[13,14]$.

The aim of this study was to isolate, characterize and identify the bacterial contaminants on used manual toothbrushes obtained from some students of Nnamdi Azikwe University Awka, Nigeria. It is hoped that the result of this study will educate the public on the need for sound oral hygiene through adequate care of their toothbrushes.

\section{Materials and Methods}

\subsection{Sample Collection}

Forty Students from Nnamdi Azikiwe University Awka, Nigeria were each given a new toothbrush of the same brand and requested to follow their normal oral hygiene practices in the morning and at night for one month. The used toothbrushes were processed within eighteen hours of their receipt from the students.

\subsection{Isolation of Bacteria}

Each of the used toothbrushes was decapitated and the head bearing the brush aseptically transferred into a tube containing ten milliliters of tryptone soya broth. The contents were allowed to stay for thirty minutes before being vortexed for sixty seconds. Ten fold serial dilutions were thereafter prepared using sterile distilled water and $0.1 \mathrm{mls}$ of appropriate dilution $\left(10^{5}\right)$ were spread plated onto sterile Mannitol salt agar, Cetrimide agar, Blood agar, Eosin methylene blue agar and MacConkey's agar, contained in petri-dishes. The media had $0.05 \mathrm{mg} / \mathrm{ml}$ of Ketoconazole added to inhibit fungal growth.

The petri dishes were then incubated aerobically at $30^{\circ} \mathrm{C}$ for twenty four hours. New (unused) toothbrushes were subjected to the same procedure as the used toothbrushes and served as controls. Colonies from the plates were thereafter purified and stored on nutrient agar slants for characterization and identification.

\subsection{Characterization and Identification of the Bacterial Isolates}

The bacterial isolates were characterized and identified on the basis of their colonial, molecular and biochemical characteristics. Gram staining, Coagulase, Catalase, Motility, Voges proskaeur, Indole production, Citrate utilization, Oxidase, Methyl red and Sugar fermentation tests were performed according to the scheme of Cheesbrough [15].

\section{Results}

Forty used manual toothbrushes were analyzed for bacterial contamination. The result showed that bacteria were isolated from all the used toothbrushes examined while the controls showed no bacterial growth.

The bacterial isolates from the used toothbrushes were identified as Streptococcus mutans, Pseudomonas aeruginosa, Enterobacter aerogenes, Escherichia coli, Staphylococcus aureus and Staphylococcus epidermidis as shown in Table 1.

Table 1. Bacterial Isolates from the Used Manual Toothbrushes

\begin{tabular}{|c|c|}
\hline Isolates & Identity \\
\hline 1 & Staphylococcus epidermidis \\
\hline 2 & Pseudomonas aeruginosa \\
\hline 3 & Escherichia coli \\
\hline 4 & Staphylococcus aureus \\
\hline 5 & Streptococcus mutans \\
\hline 6 & Enterobacter aerogenes \\
\hline
\end{tabular}

The occurrence of the bacterial isolates on the used toothbrushes is presented in Table 2. Staphylococcus aureus was most frequently isolated $(30 \%)$ followed by Pseudomonas aeruginosa (22\%), Staphylococcus epidermidis (18\%), Streptococcus mutans (16\%), Escherichia coli (8\%) while Enterobacter aerogenes had the least occurrence $(6 \%)$.

Table 2. Occurrence of the Bacterial isolates on the Used Manual Toothbrushes

\begin{tabular}{|c|c|c|}
\hline Bacterial Isolates & Number Isolated & Occurrence (\%) \\
\hline Streptococcus mutans & 8 & 16 \\
\hline Pseudomonas aeruginosa & 11 & 22 \\
\hline Staphylococcus aureus & 15 & 30 \\
\hline Escherichia coli & 4 & 8 \\
\hline Enterobacter aerogenes & 3 & 6 \\
\hline $\begin{array}{c}\text { Staphylococcus } \\
\text { epidermidis }\end{array}$ & 9 & 18 \\
\hline Total & 50 & 100 \\
\hline
\end{tabular}

The numbers of used toothbrushes positive with the bacterial isolates are shown in Table 3. Staphylococcus aureus was isolated from $60 \%$ of the samples while Pseudomonas aeruginosa, Staphylococcus epidermidis, Streptococcus mutans, Escherichia coli and Enterobacter aerogenes was isolated from 50\%, 45\%, 25\%, 20\% and 10\% of the samples.

Table 3. Used Manual Toothbrushes Positive with the Bacterial Isolates

\begin{tabular}{|c|c|c|}
\hline Bacterial Isolates & $\begin{array}{c}\text { Number of samples } \\
\text { positive with bacterial } \\
\text { isolates }\end{array}$ & $\begin{array}{c}\text { positive } \\
\text { samples (\%) }\end{array}$ \\
\hline Staphylococcus aureus & 24 & 60 \\
\hline $\begin{array}{c}\text { Pseudomonas } \\
\text { aeruginosa }\end{array}$ & 20 & 50 \\
\hline $\begin{array}{c}\text { Staphylococcus } \\
\text { epidermidis }\end{array}$ & 18 & 45 \\
\hline Streptococcus mutans & 10 & 25 \\
\hline Escherichia coli & 8 & 20 \\
\hline Enterobacter aerogenes & 4 & 10 \\
\hline
\end{tabular}




\section{Discussion}

A total of forty used manual toothbrushes obtained from forty students of Nnamdi Azikiwe University Awka, Nigeria were examined bacteriologically. The result showed that all of them were contaminated with bacteria while the unused toothbrushes which served as controls showed no bacterial growth. The contamination of the used toothbrushes by bacteria may come from the oral cavity, storage containers, storage environments, the water used for rinsing and the users.

Fifty bacterial isolates were identified from the used toothbrushes. The bacteria were Streptococcus mutans, Pseudomonas aeruginosa, Staphylococcus aureus, Staphylococcus epidermidis, Escherichia coli and Enterobacter aerogenes (Table 1). Sammons et al [13] isolated Staphylococci, Presumptive coliforms and Pseudomonas from the toothbrushes they examined while Osho et al [10] isolated Escherichia coli, Enterobacter, Staphylococcus aureus, Staphylococcus saprophyticus and Pseudomonas aeruginosa from toothbrushes after use. In addition, Malmberg et al [11] isolated Streptococci and Staphylococcus epidermidis from toothbrushes after use while Glass [12] reported that toothbrushes from both healthy patients and patients with oral disease contained potentially pathogenic bacteria such as Staphylococcus spp, Escherichia coli and Pseudomonas spp.

Bello et al [16] reported Staphylococcus, Escherichia, and Pseudomonas in used toothbrushes while Contreras et al [17] reported that the most frequent microorganisms found in toothbrushes used by parents and children for one month were Enterobacteriaceae and Pseudomonadaceae. Kozai et al [18] also reported that Streptococcus mutans and pathogenic microorganisms can be transferred readily when a toothbrush is used, increasing the risk of dental caries and infectious diseases while Nelson et al [19] also isolated Streptococcus mutans from used toothbrushes using microbiological identification.

Staphylococcus aureus was most frequently isolated from the used toothbrushes, with a percentage occurrence of $30 \%$ while Enterobacter aerogenes had the lowest percentage occurrence of $6 \%$ on the used toothbrushes examined. Sammons et al [13] however isolated Staphylococci $(48 \%)$, Presumptive coliforms (28\%) and Pseudomonas (16\%) from used toothbrushes while Osho et al [10] isolated Escherichia coli (10\%), Enterobacter (10\%), Staphylococcus aureus (20\%), Staphylococcus saprophyticus (20\%) and Pseudomonas aeruginosa (40\%). Malmberg et al [11] isolated Streptococci (50\%) and Staphylococci (86\%) from used toothbrushes.

Staphylococcus aureus was detected in $60 \%$ of the used toothbrushes examined while Enterobacter aerogenes was isolated from $10 \%$ of the samples studied. Staphylococci are common skin inhabitants. Their presence on the used toothbrushes in high numbers may come from handling and rinsing of the toothbrushes after use. They are known to produce potent toxins which are injurious to health. They are also capable of producing many oral infectious diseases.

Pseudomonas aeruginosa are opportunistic pathogens responsible for many nosocomial infections. They are also ubiquitous in nature including water. Their presence in used toothbrushes may be attributable to the storage environment such as the bathroom, toilet and washing sinks, rinsing water and the air. The bathroom provides a humid environment that encourages the growth of Pseudomonas aeruginosa.

Escherichia coli and Enterobacter aerogenes are coliforms and members of the family Enterobacteriaceae. They are also pathogenic to humans in significant numbers. The presence of Escherichia coli on the toothbrushes examined was indicative of fecal contamination. The used toothbrushes must have been stored in unhygienic environments such as toilet and bathroom sinks. These bacteria may also have entered the toothbrushes through the rinsing water.

Streptococci are aetiological agents of tooth decay and are important bacteria found on the teeth, buccal cavity and throat. Streptococcus mutans are known to cause dental caries by metabolizing different carbohydrates on the teeth. Since they are of oral origin, their presence on used toothbrushes is not surprising. Improper rinsing of the used toothbrushes may have accounted for the growth of the bacteria on the samples.

Different brands of toothbrushes are marketed to the public every year with little information on their contamination by bacteria with use. The use of uncontaminated toothbrushes will assist in the maintenance of sound oral hygiene and reduce the health risk posed by the contaminating bacteria to humans.

\section{Conclusions}

All the used toothbrushes examined in this study were contaminated with bacteria which are known to cause serious health problems in humans. Since toothbrushes serve as reservoirs for microorganisms and play a major role in disease transmission and increase in risk of infections, their care should be given adequate attention. They must be adequately rinsed with sterile water and allowed to dry in air before storage in hygienic dry containers. In addition sharing of toothbrushes should be discouraged.

\section{REFERENCES}

[1] A. Mehta, P.S. Sequeira, G. Bhat. Bacterial contamination and decontamination of toothbrushes after use. The New York State Dental Journal. Vol. 73, No. 3, 20-22, 2007. http://www.ncbi.nlm.nih.gov/pubmed/17508674.

[2] J. Downes, S.J. Hooper, M.J. Wilson, W.G. Wade. Prevotella histicola sp. nov., isolated from the human oral cavity. International Journal of Systematic and Evolutionary 
Microbiology. Vol. 58, No. 8, 1788-1791, 2008 doi:10.1099/ijs.0.65656-0.

[3] M. Efstratiou, W. Papaioannou, M. Nakou, E. Ktenas, I.A. Vrotsos, V. Panis. Contamination of a toothbrush with antibacterial properties by oral microorganisms. Journal of Dentistry. Vol. 35, No.4, 331-337, 2007. DOI: http://dx.doi.org/10.1016/j.jdent.2006.10.007.

[4] M.R. Frazelle, C.L. Munro. Toothbrush contamination: a review of the literature. Nursing Research and Practice. Vol. 2012, 420630, 2012. Doi:10.1155/2012/420630.

[5] S.S. Tagi, A.H. Rogers. The Microbial contamination of toothbrushes. A pilot study. Australian Dental Journal. Vol.43, No.2, 128-130, 1998. DOI:10.1111/j.1834-7819.1998.tb061 $01 . \mathrm{x}$.

[6] W. Wetzel, C. Schaumburg, F. Ansari, T. Kroager, A. Sziegoleit. Microbial contamination of toothbrushes with different principles of filament anchoring. Journal of American Dental association. Vol. 136, No. 6, 758-765, 2005. DOI:10.14219/jada.archive.2005.0259.

[7] S.D. Caudry, A. Klitorinos, E.C. Chan. Contaminated toothbrushes and their disinfection. Journal of Canadian Dental Association. Vol. 16, No.6, 511-516, 1995. http://www.ncbi.nlm.nih.gov/pubmed/7614433.

[8] D.A. Devine, R.S. Percival, D.J. Wood, T.J. Tuthill, P. Kite, R.A. Killington, P.D. Marsh. Inhibition of biofilms associated with dentures and toothbrushes by tetrasodium EDTA. Journal of Applied Microbiology. Vol. 103, No. 6, 2516-2524, 2007 DOI: 10.1111/j.1365-2672.2007.03491.x.

[9] M.C. Goldschmidt, D.P. Warren, H.J. Keene, W.H. Tate, C. Gowda .Effects of an antimicrobial additive to toothbrushes on residual periodontal pathogens. Journal of Clinical Dentistry. Vol. 15, No.3, 66-70, 2004. http://www.ncbi.nlm.nih.gov/pubmed/15688961.

[10] A. Osho, B.T. Thomas, Y.A. Akande, R.D. Udor. Toothbrushes as fomites. Journal of Dentistry and Oral Hygiene. Vol. 5, No.9, 92-94, 2013 DOI:10.5897/JDOH2013.0095.

[11] E. Malmberg, D. Birkhed, G. Norvenius, J.G. Noren, G.
Dahlen. Microorganisms on toothbrushes at day-care centers. Acta Odontologica Scandivanica. Vol. 52, No.2, 93-98, 1994. DOI: 10.3109/00016359409029061.

[12] R.T. Glass. The infected toothbrush, the infected denture and transmission of disease: a review. Compendum. Vol. 13, No.7, 592,594,596-598, 1992.

http://www.ncbi.nlm,.nih.gov/pubmed/1521295.

[13] R.L. Sammons, D. Kaur, P. Neal. Bacterial survival and biofilm formation on conventional and antibacterial toothbrushes. Biofilms. Vol. 1, No.2, 123-130, 2004. DOI: http://dx.doi.org/10.1017/S1479050504001334.

[14] D.P. Warren, M.C. Goldschmidt, M.B. Thompson, K. Adler-Storthz, H.J. Keene. The effects of toothpastes on the residual microbial contamination of toothbrushes. Journal of American Dental Association. Vol. 132, No. 9, 1241-1245, 2001. http://www.ncbi.nlm.nih.gov/pubmed/11665348.

[15] M. Cheesbrough. District Laboratory Practice in Tropical Countries Cambridge University Press, India. $2^{\text {nd }}$ Edition, pp 35-70, 2006.

[16] O.O. Bello, A. Osho, S.A. Bankole, T.K. Bello. Antibiotic Susceptibility Profiles and Bacteriological Risks Associated with Used Toothbrushes: A case study of some apparently healthy University students in Southwestern Nigeria. American International Journal of Biology. Vol. 1, No. 1. 1-12, 2013. aripd.org/journals/aijb/vol_No_1_July_2013/full -text-I.php.

[17] A. Contreras, R. Arce, J.E. Botero, A. Jaramillo, M. Betancourt. Toothbrushes contamination in family members. Revista Clinical de Periodoncia Implantologia Rehabilitacion Oral. Vol. 3, No. 1, 24-26, 2010 DOI: 10.406/S0719-01072010000100004.

[18] K. Kozai, T. Iwai, k. Miura. Residual contamination of toothbrush by microorganisms. ASDC Journal of Dental Child. Vol.56, No.3, 201-204, 1989. http://www.ncbi.nlm.nih.gov/pubmed//2723207.

[19] F.P. Nelson, S. Macari, G. Faria, S. Assed, I.Y. Ito. Microbial contamination of toothbrushes and their decontamination. Paediatric Dentistry. Vol. 22, No.5, 381-384, 2000. http://www.ncbi.nlm.gov/pubmed/11048305. 